\title{
PNEUMATIKUS PRÓBATEST GYORSÍTÓ TERVEZÉSI KÉRDÉSEI A LÉGFEGYVEREK ANALÓGIÁJÁN
}

\section{DESIGN QUESTIONS OF AN EXPERIMENTAL PNEUMATIC ACCELERATOR ON THE ANALOGY OF AIR GUNS}

\author{
Porkoláb Péter ${ }^{1}$, Gonda Viktor ${ }^{2}$, Varga Péter $^{3}$ \\ ${ }^{123}$ Óbudai Egyetem Bánki Donát Gépész és Biztonságtechnikai Mérnöki Kar, Anyag- \\ és Gyártástudományi Intézet, 1081 Budapest, Népszinház utca 8. \\ lpp.porkolab@gmail.com \\ '2gonda.viktor@bgk.uni-obuda.hu \\ 3varga.peter@bgk.uni-obuda.hu
}

\begin{abstract}
During the Taylor impact test, a cylindrical metal specimen is collided to an anvil with high velocity. Analyzing the deformation of the specimen, high strain rate behavior of the material can be extracted. We design a pneumatic accelerator for the test, which can be modeled as a high power gas gun, considering the analogy of an air gun. We calculate the necessary initial gauge pressure and barrel length of the accelerator, using a sample with given size and mass at desired velocity by applying equations of internal ballistics of air guns.
\end{abstract}

Keywords: Taylor test, pneumatic accelerator, air gun, internal ballistics.

\section{Összefoglalás}

A Taylor-teszt során egy hengeres alakú fém próbatestet adott sebességgel falnak lövünk, a próbatest deformációjából becsülhető a dinamikus alakítási szilárdság. A vizsgálathoz pneumatikus gyorsítót tervezünk, ami egy viszonylag nagyméretü és -teljesítményủ ún. gázágyú, ami egy légfegyverhez hasonlítható. Az adott méretű és tömegü próbatestet a kívánt sebességre gyorsító pneumatikus készülék szükséges kezdeti túlnyomását és csőhosszát a légfegyverek belballisztikájára érvényes összefüggések segítségével határozzuk meg.

Kulcsszavak: Taylor-teszt, pneumatikus gyorsitó, légfegyver, belballisztika.

\section{A Taylor ütközési vizsgálat}

A fémes szerkezeti anyagok nagy sebességü és nagymértékü alakváltozása létrejöhet lövedékek becsapódásakor, jármüvek ütközésekor, vagy nagy sebességü képlékeny alakításkor, például robbantásos vagy elektrodinamikus alakításkor. Ilyenkor a képlékeny alakváltozási sebesség mértéke $>10^{3} \mathrm{~s}^{-1}$ nagyságrendü is lehet. Az ún. Tay- lor ütközési vizsgálattal egy hengeres alakú próbatestet falnak lövünk, a deformált geometriából becsülhető a dinamikus alakítási szilárdság [1].

\section{A Taylor-vizsgálatról a légfegy- verek analógiáján}

A Taylor ütközési vizsgálathoz használt berendezés része a próbatest gyorsító, ami a hengeres próbatestnek jelentős mozgási 
energiát ad, valamint az üllö, amire nagy sebességgel becsapódik a próbatest. A teszt a próbatest deformációjának vizsgálatával eredményeket szolgáltat a nagysebességű alakváltozási folyamatokról. Müködési elv alapján a pneumatikus kialakítású gyorsító az egyik lehetséges változat.

A pneumatikus gyorsítót egy viszonylag nagyméretü és -teljesítményü légfegyvertől az különbözteti meg, hogy müszaki célokra tervezték és rendeltetésszerüen csak e célokra használható, valamint ergonómiai kialakítása is ennek megfelelő.

A légfegyverek sürített gáz segítségével gyorsítják a lövedéket a csőben, müködési elvük alapján két csoportba sorolhatók: lövés közben sürítő, más néven rugós, és sürített gázt tartalmazó tartállyal rendelkező légfegyverek [2].

Rugós légfegyverek esetén a lövés során egy megfeszített rugóval egy dugattyút gyorsítunk, ami a dugattyúházban lévő levegőt összesüríti, így létrehozva a lövedéket a csőben gyorsító túlnyomást [2].

Sürített gázt tartalmazó tartállyal rendelkező légfegyverek esetén a lövés során egy szelep nyitásával a tartályból sürített gázt juttatunk a lövedék mögé, aminek túlnyomása a lövedéket a csőben felgyorsítja. Változatai (a megnevezések a légfegyveres szakirodalomban és közösségben egyaránt használt kifejezések):

- $\mathrm{CO}_{2}$-os légfegyverek: 8, 12, és 88 grammos $\mathrm{CO}_{2}$ patron tartalmazza a sürített gázt;

- Pre-Compressed Air, azaz PCA légfegyverek: lövés előtt a dugattyú hátrahúzásával levegőt engedünk a léghengerbe, amit a dugattyú visszatolásával sürítünk;

- Pre-Charged Pressair, azaz PCP légfegyverek: 100-300 ml térfogatú, 200-300 bar nyomású sürített levegőt tartalmazó tartály található a légfegyveren [2].

A pneumatikus gyorsító modellezhető a légfegyverek belballisztikájával. A ballisztika a mechanika része, a hajított testek mozgását vizsgáló tudományág, ami az összes lőfegyverre kiterjedően vizsgálja a lövéssel összefüggő kérdéseket a lőpor égésének kezdetétől - esetünkben: rugós légfegyverek esetén a dugattyú elindulásának, sürített gázt tartalmazó tartállyal rendelkező légfegyverek esetén a szelep nyitásának pillanatától - a lövedék megállásáig. A belső ballisztika (vagy belballisztika) a lövés folyamatának első, a fegyver csövében lejátszódó szakaszával foglalkozik, amelyben a nyugalomban lévő lövedék a torkolati sebességre gyorsulva elhagyja a fegyver csövét [3].

\section{A pneumatikus gyorsító és a lég- fegyverek néhány tervezési kérdése}

A pneumatikus gyorsító tervezésénél a kiinduló adatok a próbatest geometriája és sebessége. A hengeres próbatest méreteit esetünkben $8 \mathrm{~mm}$-es átmérővel és $25 \mathrm{~mm}$ hosszal határoztuk meg. A próbatest torkolati sebességét szakirodalomban közölt eredmények alapján maximum 300 m/s-ban határoztuk meg. A berendezés tervezése során a következő anyagokhoz számoljuk a szükséges nyomás értékét: volfrám, ólom, réz, vas és alumínium. Így biztosítható, hogy a berendezéssel bármilyen müszaki gyakorlatban alkalmazott anyagminőség vizsgálható legyen a követelményként kitüzött torkolati sebességgel.

A berendezés megtervezésének következő lépése az adott keresztmetszetü és tömegü próbatest maximális torkolati sebességét megvalósító kezdeti nyomás és csőhossz összetartozó értékpárok meghatározása, amik közül kiválasztható és kiválasztandó a megvalósítás szempontjából reális és optimális érték. A kezdeti nyomás és csőhossz értékeket megadó képletekhez a sürített gázt tartalmazó tartállyal rendelkező légfegyverek belballisztikájának vizsgálatával juthatunk. Természetesen rugós légfegyverek müködési elvén alapuló gyorsító is szerkeszthetö, de annak tervezési számí- 
tásai bonyolultabbak, valamint nem biztosítható a számítások eredményeivel összhangban lévő rugó müszaki megvalósíthatósága, míg megfelelő szelep katalógusból kiválasztható és rendelhető.

A pneumatikus gyorsító csövében a táguló sürített levegő gyorsítja a próbatestet a kívánt torkolati sebességre. A folyamatról a következő elfogadható egyszerüsítéseket feltételezzük:

- a levegö ideális gáz;

- a sürített levegö tágulása izotermikus;

- a csőben a próbatestre ható légellenállás elhanyagolható;

- a csőben a próbatestre ható súrlódási erő a próbatest sebességétől független, állandó;

- a próbatest nem zömül a nyomás hatására, a súrlódási erőhöz szükséges összeszorító erőt kizárólag a próbatest súlya biztosítja (feltételezzük, hogy a csőtengely vízszintes, így a legnagyobb súrlódási erővel számolunk);

- a próbatest tökéletesen illeszkedik a csőfuratba, a sürített levegő nem fúj le a próbatest és a csőfal közötti résen;

- a sürített levegő gyorsítására fordított energia elhanyagolható;

- a berendezés csöve sima furatú, a próbatest huzagolás általi megforgatására nem kell energiát fordítani.

A fenti egyszerüsítések mellett a szakirodalom szerint a következő egyenlet adja meg a próbatest mozgási energiáját a csőtengely mentén elfoglalt helyzete függvényében [4]:

$$
\frac{1}{2} m v^{2}(x)=p_{0} V_{0} \ln \left(1+\frac{A x}{V_{0}}\right)-F_{\text {sirl }} x
$$

ahol:

- $\quad V_{0}\left[\mathrm{~m}^{3}\right]$ a sürített levegő kezdeti térfogata;

- $\quad p_{0}[\mathrm{~Pa}]$ a sürített levegő kezdeti nyomása, ami túlnyomás: így nem kell az egyenletben a próbatestre ható légköri nyomás hatásával számolni;
- $A\left[\mathrm{~m}^{2}\right]$ a próbatest keresztmetszete, amire a sürített levegö nyomása hat;

- $\quad x[\mathrm{~m}]$ a próbatest helyzete a csőtengely mentén: legnagyobb értéke a csőhossz lehet;

- $\quad v[\mathrm{~m} / \mathrm{s}]$ a próbatest sebessége;

- $m[\mathrm{~kg}]$ a próbatest tömege;

- $\quad F_{\text {súrl }}[\mathrm{N}]$ az állandónak feltételezett súrlódási erő.

A próbatest mozgási energiáját megadó egyenletből levezethető a szükséges $p_{0}$ kezdeti túlnyomást megadó egyenlet, ha a próbatest $v_{\max }$ legnagyobb torkolati sebessége és a csőhossz, $l$ adott:

$$
p_{0}=\frac{\frac{1}{2} m v_{\max }^{2}+F_{\text {sirr }} l}{V_{0} \ln \left(1+\frac{A l}{V_{0}}\right)},
$$

valamint a szükséges $l$ csőhossz, ha a próbatest $v_{\max }$ legnagyobb torkolati sebessége és a $p_{0}$ kezdeti túlnyomás adott:

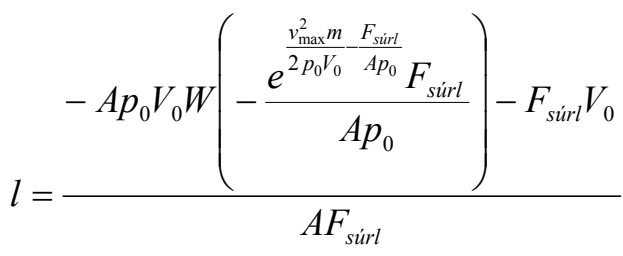

ahol $W$ a Lambert-féle logaritmus-szorzat függvény.

A müszaki gyakorlatban tökéletesen elfogadható eredményt ad a numerikus megoldás is, amikor az (1) egyenletbe behelyettesítve adott kezdeti túlnyomás mellett több különböző csőhossz esetén kiszámítjuk a próbatest mozgási energiáját, és kiválasztjuk a próbatest kívánt mozgási energiájával megegyezö, vagy ahhoz legközelebb eső csőhosszt. Megjegyzendő, hogy a gyakorlatban a tartálytérfogat a cső belső térfogatánál jóval nagyobb, ezért a tartály térfogata csak kis mértékben befolyásolja a szükséges nyomást, vagy a cső hosszának kiválasztását. 


\section{Eredmények és következtetések}

Számításaink alapján kör keresztmetszetü, $8 \mathrm{~mm}$ átméröjü, $25 \mathrm{~mm}$ hosszú (14,3 gramm tömegü) ólom próbatest 300 $\mathrm{m} / \mathrm{s}$ torkolati sebességre gyorsításához 2 literes $\left(0,002 \mathrm{~m}^{3}\right)$ sürített levegös tartály (kezdeti térfogat) alkalmazásával 12,9 MPa (129 bar) kezdeti túlnyomás szükséges $1 \mathrm{~m}$ csőhossz esetén, a súrlódóerőt 0,014 N-ra felvéve. Különbözö anyagminőségek esetén - a geometriai adatokat lekötve - a tömeget

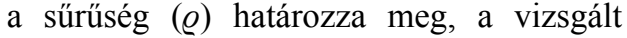
anyagoknál a számításban $\varrho_{\mathrm{W}}=19250$ $\mathrm{kg} / \mathrm{m}^{3}, \varrho_{\mathrm{Pb}}=11340 \mathrm{~kg} / \mathrm{m}^{3}, \varrho_{\mathrm{Cu}}=8960$ $\mathrm{kg} / \mathrm{m}^{3}, \varrho_{\mathrm{Fe}}=7850 \mathrm{~kg} / \mathrm{m}^{3}, \varrho_{\mathrm{Al}}=2700 \mathrm{~kg} / \mathrm{m}^{3}$ sürüségeket felhasználva a szükséges kezdeti túlnyomást ábrázoltuk az elérni kívánt torkolati sebesség függvényében az 1. ábrán.

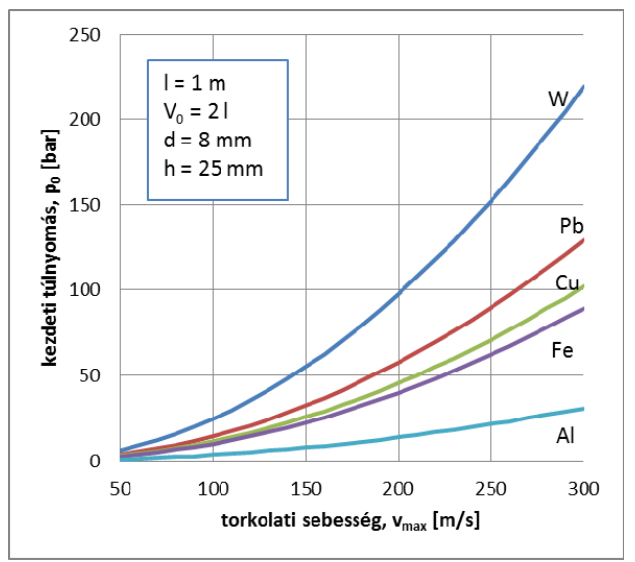

1. ábra. A szükséges túlnyomás a kivánt torkolati sebesség eléréséhez különbözö anyagú próbatestek esetén
A (2) egyenlet paramétereinek a hatása a szükséges túlnyomásra a következőképpen foglalható össze: a gyorsításhoz szükséges túlnyomás egyenesen arányos a próbatest sủrüségével és hosszával, az elérni kívánt sebesség négyzetével, valamint fordítottan arányos a gyorsító csőhosszával. Mivel a tartálytérfogat a cső belső térfogatánál jóval nagyobb, ezért a tartály térfogata csak kis mértékben befolyásolja a szükséges nyomást. A próbatest és cső belső keresztmetszeti felülete azonos, ezért a nyomás értékét ebben a modellben nem befolyásolja. A súrlódó erő felvett kis értékét változtatva ebben a tartományban csak kb. $1 \%$-al befolyásolja a szükséges nyomás értékét.

\section{Köszönetnyilvánítás}

A dolgozat a Bolyai János Kutatási Ösztöndíj támogatásával készült.

\section{Szakirodalmi hivatkozások}

[1] Varga Péter, Gonda Viktor, Rácz Pál: Taylor-teszt modellezése a Johnson-Cook anyagmodell alkalmazásával: a hömérséklet hatása. A XX. Fiatal Müszakiak Tudományos Ülésszaka előadásai. Kolozsvár, Erdélyi Múzeum-Egyesület, 2015. ISSN 2393-1280 p. 327-330.

[2] Pongrátz Gábor: Akié a választás, azé a gyötrelem... - Légpuskák kezdöknek - piaci körkép. Kaliber Évkönyv, 2008. ISSN 1418513X p. 58-59.

[3] Kiss A. Péter: A gépkarabély és használata. Budapest, Zrínyi Kiadó. ISBN 963327317 X p. 19. col. 1.

[4] Mark Denny: The Internal Ballistics of an Air Gun. The Physics Teacher, 2011. 2. szám. ISSN 0031 921X 